\title{
The Sepsidae from Sri Lanka, with description of a new species (Diptera)*
}

\author{
Mitsuhiro IwasA ${ }^{* *}$ and Nalini JAYASE KERA ${ }^{* * *}$ \\ ** Laboratory of Entomology, Obihiro University of Agriculture and Veterinary Medicine, \\ Obihiro 080, Japan \\ *** Department of Entomology, Medical Research Institute, Colombo 8, Sri Lanka
}

(Received: September 6, 1993)

Key words: Diptera, Sepsidae, new species and new records, Sri Lanka.

\begin{abstract}
Twelve species belonging to five genera of Sepsidae including a new species, Dicranosepsis prominula, and four newly recorded species are described and recorded from Sri Lanka. An identification key to the genera and species of Sri Lanka is given.
\end{abstract}

\section{INTRODUCTION}

The flies of the family Sepsidae of the Southwest Asia have been reported from India (Brunetti, 1909; Duda, 1926; Zuska, 1974, 1977; Iwasa, 1982; Iwasa and Tewari, 1990), Nepal (Zuska, 1968; Iwasa, 1984), Pakistan (Iwasa, 1989) and Bangladesh (Iwasa et al., 1991). Those of Sri Lanka were recorded as distributional data by Zuska (1977) in the Oriental Catalog, but there has been virtually no work on the sepsid fauna of Sri Lanka.

Recently, I had a chance to examine the sepsid specimens of Sri Lanka collected by

* Contribution No. 156 from the Laboratory of Entomology, Obihiro University of Agriculture and Veterinary Medicine. This study was supported by the Grant-in-Aid for Monbusho International Scientific Research Program (Field Research) to the Toyama Medical and Pharmaceutical University in 1986, 1987 and 1988 (Grant No. 61042004, 62041036, 63041058). ZDSA series No. 25.

** 岩佐光啓: 帯広畜産大学畜産環境科学科生態系保 護学講座昆虫学教窒 (テ080 帯広市稲田町西 2 線 11) myself and other members of the "Zoogeographical Studies on the Medically Important Diptera in Southwest Asia (19871988)." As a result of the examination, twelve species of five genera were determined. In the present paper, I describe one new species and give the records of eleven species including four newly recorded species with a key to the species occurring in Sri Lanka.

\section{Key to the genera and species}

1. Thorax and abdomen wholly black and dully shiny; middle femur bent on middle part; large species, body length about $6 \mathrm{~mm}$.... Toxopoda Macquart .... 2 Thorax and abdomen black, red or yellow and shiny; middle femur not bent on middle part; medium or small species, body length less than $5 \mathrm{~mm} \ldots \ldots \ldots 3$

2. Male epandrial processes slender and

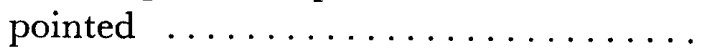
... T. mordax Iwasa, Zuska et Ozerov Male epandrial processes not slender .. .......... T. contracta (Walker)

3. Humeral setae absent ............. Decachaetophora aeneipes (De Meijere) 
Humeral setae present .........4 4

4. Fronto-orbital setae developed ........ ..... Meroplius fasciculatus (Brunetti) Fronto-orbital setae vestigial or absent .................... 5

5. First and second basal cells united ..... ....... Australosepsis Malloch ...6 6 First and second basal cells separated .. ...................... 7

6. Wing with a diffused dark spot at the end of vein $R_{2+3} \ldots \ldots \ldots \ldots \ldots$ .......... niveipennis (Becker) Wing without a diffused dark spot at the end of vein $R_{2+3} \ldots \ldots \ldots \ldots \ldots$ ............ frontalis (Walker)

7. Abdomen in both sexes without distinct macrochaetae; male epandrial processes bifurcate at the tip ............. ......... Dicranosepsis Duda ... 8 Abdomen in male, and often in female also, with distinct macrochaetae; male epandrial processes not bifurcate at the tip ........... Sepsis Fallén ... 9

8. Male epandrial processes with triangular projection on upper one ........... ............ D. prominula n. sp. Male epandrial processes without a triangular projection ............... ......... D. bicolor (Wiedemann)

9. Wing with a dark spot at the end of vein $R_{2+3} \ldots \ldots \ldots \ldots \ldots \ldots \ldots \ldots \ldots \ldots \ldots$ Wing without a dark spot at the end of vein $R_{2+3} \ldots \ldots \ldots \ldots \ldots \ldots \ldots$

10. Sternopleuron almost shiny, only posterodorsal margin thinly pruinose; male fore femur with anterobasal patch of long hairs ......... S. albopunctata Lamb Stenopleuron posterodorsally pruinose; male fore femur without anterobasal patch of long hairs .............. ...... S. thoracica Robineau-Desvoidy

11. Sternopleuron posterodorsally pruinose . ........... S. lateralis Wiedemann Sternopleuron wholly pruinose . . . 12

12. Pteropleuron pruinose ............ ............. S. indica Wiedemann Pteropleuron shiny .......... 13

13. Male epandrial processes short and slender .......... nitens Wiedemann Male epandrial processes long and stout
S. coprophila de Meijere

\section{Toxopoda mordax Iwasa, Zuska et Ozerov, 1991}

Toxopoda mordax Iwasa, Zuska et Ozerov, 1991, Jpn. J. Sanit. Zool., 42: 232.

Specimens examined. 2, Nuwara Eliya, 27 Sep. 1987, M. Iwasa; 3ô, 24 Jul. 1989, $\mathrm{K}$. Kanmiya.

Distribution. Bangladesh and Sri Lanka. New record from Sri Lanka.

\section{Meroplius fasciculatus (Brunetti, 1909)}

Sepsis fasciculatus Brunetti, 1909, Rec. Ind. Mus., 3: 365.

Specimens examined. $2 \hat{\delta}, 1$, Ratnapura, 1 Oct. 1987, M. Iwasa; 4ㅅ, 2 ㅇ, Ella, 24 Jul. 1989, T. Hayashi; $3 \hat{o}$, Ella, 24 Jul. 1989, K. Kanmiya.

Distribution. Oriental region and New Guinea.

\section{Sepsis albopunctata Lamb, 1914}

Sepsis albopunctata Lamb, 1914, Trans. Linn. Soc. Lond., 2: 323.

Specimens examined. $3 \hat{\delta}$, Nuwara Eliya,

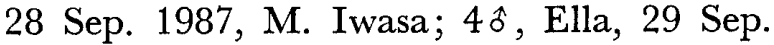
1987, M. Iwasa; $22 \hat{o}$, Ratnapura, 30 Sep.-2 Oct. 1987, M. Iwasa.

Distribution. Widely distributed in the Oriental, Afrotropical and Australasian regions. New record from Sri Lanka.

\section{Sepsis thoracica} (Robineau-Desvoidy, 1830)

Micropeza thoracica Robineau-Desvoidy, 1830, Essai Myodaires, p. 742.

Specimens examined. $5 \hat{\delta}, \mathrm{Mt}$. Pidulutagala, Nuwara Eliya, 25 Sep. 1987, M. Iwasa;

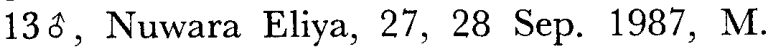
Iwasa.

Distribution. Widely distributed in the Oriental, Palaearctic and Afrotropical regions. 


\section{Sepsis lateralis Wiedemann, 1830}

Sepsis lateralis Wiedemann, 1830, Auss. zweifl. Insekt., 2: 468.

Specimens examined. $22 \hat{\jmath}$, Nuwara Eliya, 26-28 Sep. 1987, M. Iwasa; 4to, Adam's peak, Ratnapura, 2 Oct. 1987, M. Iwasa.

Distribution. Widely distributed in the Oriental, Afrotropical regions, Mediterranean subregion and New Guinea.

\section{Sepsis indica Wiedemann, 1824}

Sepsis indica Wiedemann, 1824, Analecta Ent., p. 57.

Specimens examined. $19 \hat{\text { s. }}$, Mt. Pidulutagala, Nuwara Eliya, 25 Sep. 1987, M. Iwasa;

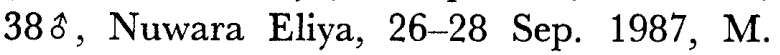
Iwasa; $8 \hat{\delta}$, Ratnapura, 1 Oct. 1987, M. Iwasa; $2 \hat{o}$, Adam's peak, Ratnapura, 2 Oct. 1987, M. Iwasa; $8 \hat{\delta}$, Sinharaja Fore., Ratnapura, 3 Oct. 1987, M. Iwasa and S. Inaoka; 2 ô, Gilimale, Ratnapura, 4 Oct. 1987, M. Iwasa.

Distribution. Widely distributed in the Oriental region.

\section{Sepsis nitens Wiedemann, 1824}

Sepsis nitens Wiedemann, 1824, Analecta Ent., p. 58.

Specimens examined. $1 \hat{t}$, Nuwara Eliya, 28 Sep. 1987, M. Iwasa; $10 \hat{o}$, Ella, 29 Sep. 1987, M. Iwasa; 2 ô, Ratnapura, 1 Oct. 1987, M. Iwasa.

Distribution. Widely distributed in the Oriental and Australasian regions.

\section{Sepsis coprophila de Meijere, 1906}

Sepsis coprophila de Meijere, 1906, Ann. Mus. Nat. Hung., 4: 176.

Specimens examined. $13 \hat{\delta}$, Ratnapura, 1 Oct. 1987, M. Iwasa; 1ڤ, Adam's peak, Ratnapura, 1987, M. Iwasa; $2 \hat{o}$, Sinharaja Fore., Ratnapura, 3 Oct. 1987, M. Iwasa.

Distribution. Widely distributed in the Oriental and Australasian regions.

\section{Australosepsis niveipennis (Becker, 1903)}

Sepsis niveipennis Becker, 1903, Mitt. zool. Mus. Berl., 2: 143.

Specimens examined. $2 \hat{\delta}$, Nuwara Eliya, 28 Sep. 1987, M. Iwasa; $3 \hat{\delta}$, Ella, 29 Sep. 1987, M. Iwasa; 1 ô, Ratnapura, 1 Oct. 1987, M. Iwasa.

Distribution. Widely distributed in the Oriental, Afrotropical and Australasian regions. New record from Sri Lanka.

\section{Australosepsis frontalis (Walker, 1860)}

Sepsis frontalis Walker, 1860, J. Proc. Linn. Lond. Zool., 4: 163.

Specimens examined. $13 \hat{\text { }}, 5$ \% , Ella, 29 Sep. 1987, M. Iwasa; $19 \hat{\delta}, 2 \%$, Sinharaja Fore., Ratnapura, 30 Sep. 1987, M. Iwasa; $5 \hat{o}$, Ratnapura, 1 Oct. 1987, M. Iwasa; $3 \hat{o}$, 2 ㅇ, Gilimale, Ratnapura, 4 Oct. 1987, M. Iwasa.

Distribution. Widely distributed in the Oriental Region and New Caledonia.

\section{Dicranosepsis prominula Iwasa}

$$
\text { n. sp. (Figs. 1-6) }
$$

Male. Head: frons black and shiny; face brown and pruinose; gena and occiput black and thinly pruinose; all antennal segments dark brown; arista black and bare; vibrissal angle with 3 moderately developed setae; genal lower margin with 10-12 peristomal setae in a line; 1 oc, 1 vti, 1 vte, 1 put; or absent.

Thorax: wholly black; mesonotum and scutellum thinly pruinose; propleuron pruinose; mesopleuron shiny; sternopleuron anteroventrally shiny and posterodorsally pruinose; pteropleuron, hypopleuron and metapleuron entirely pruinose; postscutellum partly shiny; metanotum shiny; $1 h, 2 n, 2 d c$, $1 \mathrm{sa}, 1 \mathrm{pa}, 1 \mathrm{~m}, 1$ ap sc; 1 bsc (small).

Wings: hyaline, slightly tinged with brown; veins dark brown; humeral cell and basal part of costal cell light brown; alula without distinct posterodistal lobe, and with micro- 


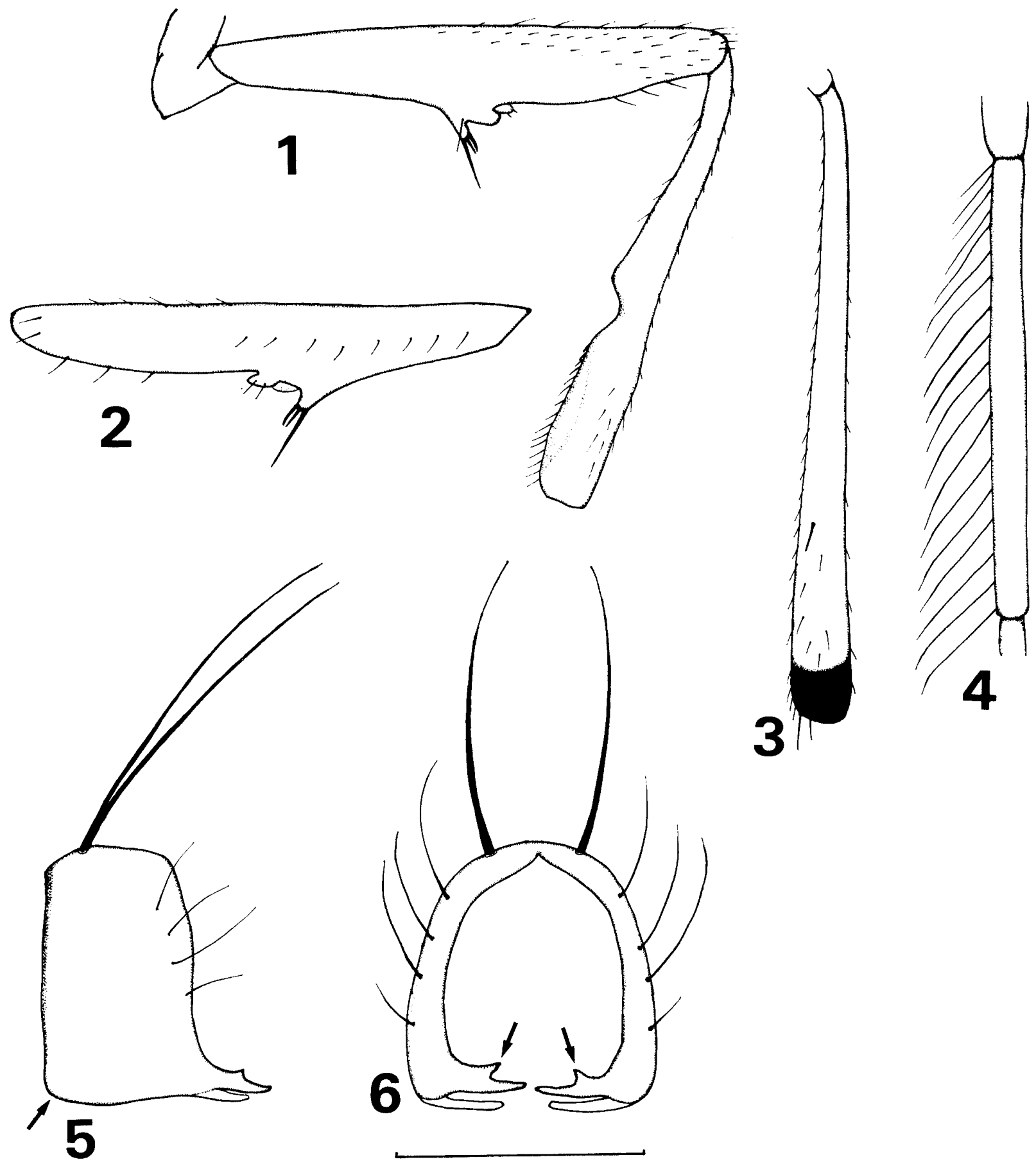

Figs. 1-6 Dicranosepsis prominula n. sp.

1: male fore femur and tibia, anterior view (left). 2: male fore femur, posterior view (left). 3: male middle tibia, anterior view (left). 4: male hind metatarsus, dorsal view (left). 5: male epandrium, lateral view (left). 6: male epandrium, posterior view. Scales: $0.25 \mathrm{~mm}$.

trichia marginally; halteres whitish, darkened basally.

Legs: all coxae, femora and tibiae yellow; fore trochanter without a sharped triangular projection ventrally; fore femur (Figs. 1,2) medianly with a ventral process which is accompanied with one long and two short spines; middle and hind femora without any distinct setae or spines; fore tibia ventrally hollowed at middle part (Fig. 1); middle 
tibia with black ring in distal end (Fig. 3); 1st to 3rd tarsal segments yellow and 4th to 5 th segments dark brown in all tarsi; hind metatarsus with a row of long bristles anteriorly (Fig. 4).

Abdomen: black and shiny; tergites sparsely clothed with bristles; 3rd segment slightly constricted basally; 4th to genital segments somewhat compressed; anteroventral part of epandrium perpendicular (Fig. 5; arrow); a pair of dorsal setae on epandrium longer than length of epandrium (Figs. 5, 6) ; upper part of bifurcate process with a triangular projection (Fig. 6; arrows).

Body length: $2.5-3.0 \mathrm{~mm}$.

Female. Unknown.

Holotype: $\delta$, Ratnapura, Sri Lanka, 1 Oct. 1987, M. Iwasa (preserved in Obihiro University of Agriculture and Veterinary Medicine). Paratypes: $12 \hat{\delta}$, same data as holotype; $5 \hat{\delta}$, Gilimale, Ratnapura, 4 Oct. 1987, M. Iwasa; $3 \hat{\delta}$, Ratnapura-Colombo, 5 Oct. 1987, M. Iwasa; 1 ô, Wellawaya, 26 Jul. 1989, K. Kanmiya.

Distribution. Sri Lanka.

Remarks. This species is closely related to Dicranosepsis tibialis Iwasa et Tewari, but differs from it in making a perpendicular angle on anteroventral part of epandrium (arrow in Fig. 5), and in having a triangular projection on upper part of bifurcate epandrial process (arrows in Fig. 6) and a row of long bristles on anterior surface of hind metatarsus in male (Fig. 4).

\section{Dicranosepsis bicolor (Wiedemann, 1830)}

Sepsis bicolor Wiedemann, 1830, Auss. zweifl. Insekt., 2: 468.

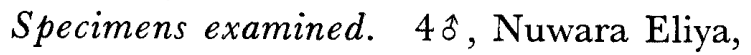
25-28 Sep. 1987, M. Iwasa; 4ㅅ, Sinharaja Fore., Ratnapura, 1 Oct. 1987, M. Iwasa; $5 \hat{o}$, Ratnapura, 1 Oct. 1987, M. Iwasa; $1 \hat{o}$, Adam's peak, Ratnapura, 2 Oct. 1987, M. Iwasa; $17 \hat{o}$, Gilimale, Ratnapura, 4 Oct. 1987, M. Iwasa.

Distribution. Widely distributed in the Oriental region.

\section{ACKNOWLEDGEMENTS}

We wish to express our sincere thanks to Dr. $\mathbf{K}$. Kamimura (Toyama Medical and Pharmaceutical University, a project leader of this survey) for giving us an opportunity to study the Sepsidae in Sri Lanka. We are also much grateful to Drs. K. Kanmiya of Kurume University; T. Hayashi of National Institute of Health; T. Inaoka of Asahikawa Medical College for their kindness in offering the valuable materials. Our thanks are also due to Prof. K. Hori of Obihiro University of Agriculture and Veterinary Medicine and Dr. S. Shinonaga of Tokyo Medical and Dental University for reading the manuscript.

\section{REFERENCES}

Brunetti, E. (1909): New Oriental Sepsinae. Rec. Indian Mus., 3: 343-372.

Duda, O. (1926): Monographie der Sepsiden II. Ann. Naturhist. Mus. Wien, 40: 1-110.

Iwasa, M. (1982): A new species and some records of Sepsidae from India (Diptera). Kontŷu, 50: 604-609.

Iwasa, M. (1984): The Sepsidae from Nepal, with descriptions of eight new species (Diptera). Kontyû, 52: 72-93.

Iwasa, M. (1989): Taxonomic study of the Sepsidae (Diptera) from Pakistan. Jpn. J. Sanit. Zool., 40 (Suppl.) : 49-60.

Iwasa, M. and R. R. Tewari (1990): Two new species of the genus Dicranosepsis Duda from India. Jpn. J. Entomol., 58: 794-798.

Iwasa, M., J. Zuska and L. Ozerov (1991): The Sepsidae from Bangladesh, with description of a new species (Diptera). Jpn. J. Sanit. Zool., 42: 229-234.

Zuska, J. (1968). Diptera from Nepal. Sepsidae. J. Nat. Hist., 2: 131-136.

Zuska, J. (1974) : Asian Themira (Diptera: Sepsidae): Descriptions of two new species and distributional notes. Proc. Entomol. Soc. Wash., 76: 190-197.

Zuska, J. (1977): Family Sepsidae. In: A Catalog of the Diptera of the Oriental Region (ed., Delfinado, M. D. and D. E. Hardy), Vol. 3, pp. 174-181, Univ. Hawaii Press, Honolulu.

\section{摘 要 \\ スリランカのツヤホソバェ類および 1 新種の記載（双翅目）}

スリランカのツヤホソバエ類については，これまで 断片的な報告しかなかった. 1987年に行われた文部省 海外学術調査「南西アジアにおける人畜有害双翅類昆 虫の動物地理学的研究」のスリランカでの調查におい 
て採集されたツヤホソバエ科八エ類を調べた結果， 5 属12種を同定した.これらのうち，1 種を新種として 記載し， 4 新記録種を含む11種を記録した。また, 従 来知られていた 1 属 2 種を加え, 計 6 属 14 種の検索表 を付した. 新種のDicranosepsis prominula は, イン
ドから記載された D. tibialis Iwasa et Tewari に類 似しているが, 雄の交尾器の epandrium の先端部 (二 又の上部）に三角状の突起を有すること, epandrium の腹面基部が直角を成すこと, および雄の後脚第一跗 節に長い剛毛列を有することなどにより区別できる。 